\title{
ANALISIS KUALITAS LAYANAN PADA JARINGAN INTERNET SISTEM KUOTA DI IAIN PALOPO
}

\author{
Rosdiana $^{1}$ \\ ${ }^{1}$ Dosen Fakultas Tarbiyah dan Ilmu Keguruan IAIN Palopo \\ 1'
}

\begin{abstract}
Abstrak
Peranan dari pembagian quota bandwidth sangat mempengaruhi $Q o S$ dari trafik. Oleh Karena itu untuk mendapatkan $Q o S$ yang baik, diperlukan pengaturan pemakaian bandwidthh dalam jaringan sebaik mungkin. Cara yang bisa di pakai dengan teknik klasifikasi paket data $C B Q$ (Class Based Quеuе) yang sudah diterapkan atau HTB (Hierarchy Token Bucket) yang merupakan teknik terbaru. Kualitas layanan jaringan internet IAIN Palopo pada dasarnya sudah memenuhi standar Quality of Service jika dilakukan penerapan Quota Bandwidthh hal ini karena diterapkannya sistem Bandwidthh Controller sehingga performa dari jaringan internet sangat baik. Solusi yang disarankan dalam mengurangi terjadinya pemakaian bandwidth yang overload, dengan cara melakukan pembatasan halaman web yang bersifat hiburan seperti media sosial maupun youtube. Disamping itu juga adanya pemisah jalur koneksi untuk lokal dan internasional. Pemakaian jaringan melebihi total bandwidthh akan mengakibatkan terjadinya packet loss. Penelitian ini mengemukakan pentingnya penyedian jaminan $Q o S$ yang dilengkapi dengan aplikasi monitoring EtE $Q M$. Lebih jauh, penelitian ini memaparkan arti pentingnya aplikasi monitoring $Q o S$ dalam jaringan Internet.
\end{abstract}

Kata kunci : Bandwidth, Quota Bandwidth, QoS, Kualitas Jaringan Internet

\section{PENDAHULUAN}

Perkembangan teknologi di bidang informasi berbasis internet, begitu pesat. Untuk mendapatkan informasi yang cepat akan sesuatu hal sudah menjadi kebutuhan bagi banyak orang. Sayangnya perkembangan teknologi yang seharusnya bisa dinikmati banyak unsur belum terwujud dikarenakan beberapa hal diantaranya layanan kualitas jaringan internet itu sendiri.

Teknologi Internet saat ini bukanlah hal yang baru bagi sebagian besar masyarakat. Demikian pula pengunaan teknologi ini sudah diaplikasikan pada sebagian besar instansi baik perusahaan pemerintahan, swasta maupun institusi pendidikan. Institut Agama Islam Negeri (IAIN PALOPO) telah menerapkan teknologi ini sebagai bagian yang sangat dibutuhkan oleh seluruh komponen dalam lingkup IAIN Palopo, yaitu staff, dosen maupun mahasiswanya. Penerapan teknologi yang tidak diimbangi dengan manajemen/pengelolaan yang baik tentunya akan mengecewakan konsumen yang sangat bergantung pada aplikasinya.

Jaringan internet merupakan jaringan (network) komputer yang terdiri dari ribuan jaringan komputer independen yang dihubungkan satu dengan yang lainnya. Internet juga menggunakan protokol TCP/IP. Protokol ini memungkinkan suatu komputer mengirim dan memberi alamat data ke komputer lain sekaligus memastikan pengiriman data sampai tujuan dengan tanpa kurang apa pun. Di IAIN Palopo jaringan internet yang ada dibangun dengan menggunakan sistem kuota bandwidth dengan pembagian berdasarkan masing-masing unit kerja dengan pembagian bandwidth berdasarkan kebutuhan.

Bandwidth (lebar band) menunjukkan sejumlah data yang dapat ditransmisikan untuk satu unit waktu yang dinyatakan dalam satuan bit per second (bps) atau character per second (cps). Bandwidth dapat dipakai untuk mengukur aliran data analog maupun aliran data digital. Pembagian kuota pada jaringan internet IAIN Palopo terdiri dari 4 bagian yaitu baypass, aplikasi, dosen dan mahasiswa. 
Semakin besar kebutuhan untuk koneksi jaringan suatu unit kerja maka kuota bandwidth yang disediakan oleh teknisi juga semakin besar. Pembagian kuota bandwidth inipun juga diberikan kepada mahasiswa dengan cara masing-masing siswa dapat memperoleh user name berikut password-nya melalui teknisi TI (Teknologi Internet) yang ditugaskan dengan memperlihatkan kartu identitas mahasiswa yang bersangkutan. Hal ini dilakukan untuk menghindari terjadinya pemakaian bersama IP-Address yang disediakan.

Layanan kualitas dari suatu jaringan internet sangat memegang peranan penting dalam penyelesaian beberapa tugas yang hanya dapat diselesaikan melalui koneksi jaringan komputer. Untuk itu evaluasi kinerja dari jaringan internet yang ada perlu mendapat perhatian besar untuk kelancaran tugas semua unit kerja yang ada.

Layanan Kualitas (Quality of Service-QoS) dari suatu jaringan internet adalah hal mutlak yang perlu diperhatikan kehandalannya untuk mendaptkan koneksitas jaringan yang berkualitas. Olehnya itu berdasarkan pemaparan di atas maka penulis ingin mencoba menganalisa Kualitas Layanan Jaringan Internet pada IAIN Palopo sehingga dapat menemukan solusi-solusi untuk penanganan dari permasalahan yang mungkin terjadi.

Jaringan IAIN Palopo adalah jaringan yang menggunakan Internet Service Provider (ISP) ASTINET dengan lebar Bandwidth sebesar 8 Mbps. Menggunakan dua tower sebagai pemancar dengan pembagian jaringan menggunakan access point yang banyak, dengan rincian peletakkan sebagai berikut: Gedung Rektorat sebanyak 6 access point, Gedung P2M sebanhyak 2 access point, Gedung Gedung Pasca, Tarbiyah dan Puskom masing-masing sebanyak 2 access point, dan Gedung N, H, Perpustakaan,Dakwah, Lab Komputer, Mess, Rumah Jabatan masing-masing 1 (satu) access point.

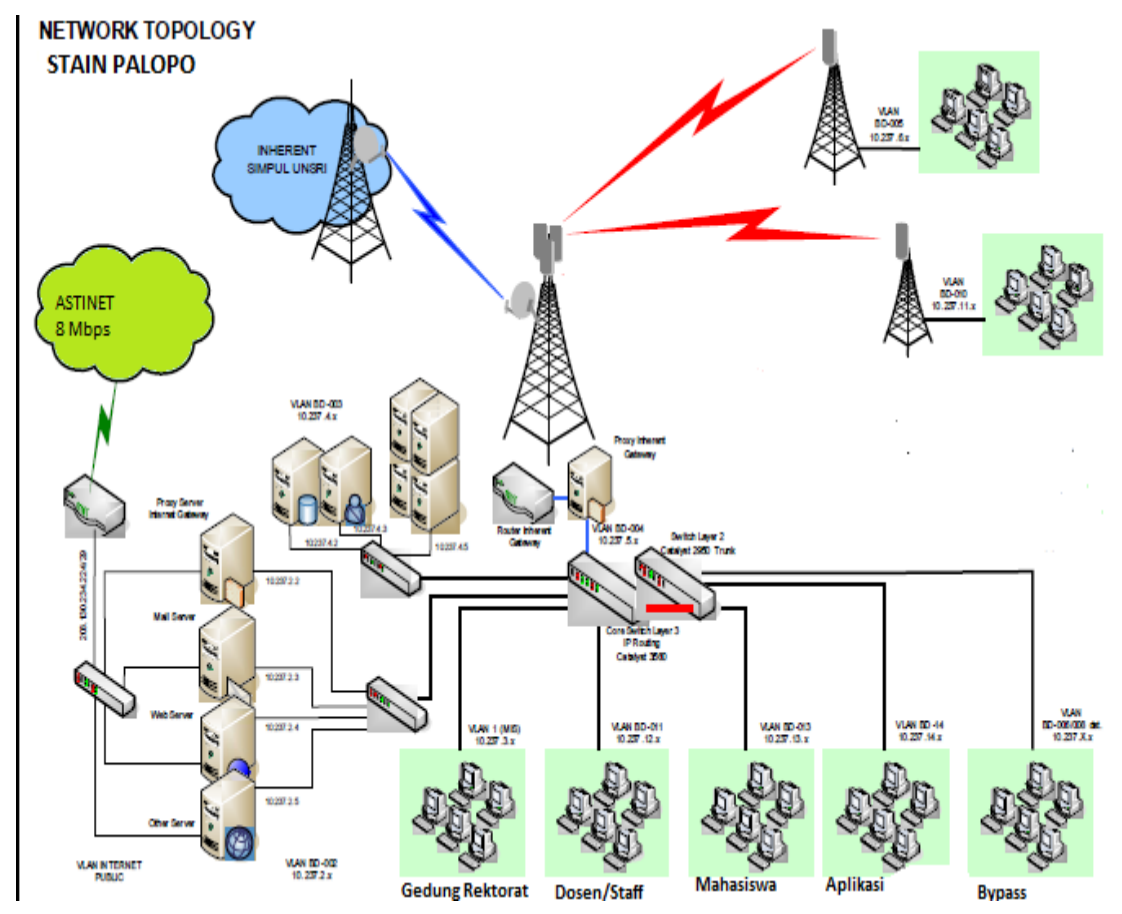

Gambar 1. Topology jaringan internet IAIN Palopo 
Untuk mengimplementasikan rencana yang sudah disusun, maka Model dari sistem monitoring $Q o S$ yang di gunakan untuk pengukuran EtE $Q M$ pada jaringan Internet IAIN Palopo untuk pengukuran parameter $Q o S$ yang terdiri dari bandwidth, throughput, delay, jitter dan packet loss adalah model monitoring QoS. Adapun tahapannya terdiri dari :

a) Monitoring Application. Monitoring application berfungsi sebagai antar muka pengguna aplikasi jaringan Internet.

b) QoS Monitoring. Mekanisme QoS monitoring untuk pengukuran EtE QM pada skema jaringan Internet untuk pengukuran parameter Bandwidth dan throughput dengan menggunakan Biznet Speed Meter, parameter throughput, Delay dan Packet loss dengan menggunakan aplikasi Axence NetTools Professional sedagkan untuk parameter jitter dengan Iperf.

c) Monitored Objects. Parameter yang di ukur dalam jaringan Internet untuk monitoring EtE QM terdiri dari bandwidth, throughput, delay, jitter dan packet loss ratio dimana dimonitor pada waktu nyata selama selang Bulan Mei-Oktober 2014. Pengukuran dilakukan pada saat jam sibuk berkisar antara pukul 09.00 sampai 12.00 WIB dan pukul 13.00 sampai 15.00 WIB dimana trafik berkisar antara $90 \%-99 \%$.

\section{HASIL DAN PEMBAHASAN}

Setelah dilakukan implementasi (action taking) dengan model sistem monitoring $Q o S$ untuk pengukuran tiap perangkat enduser pada parameter $Q o S$ model jaringan LAN IAIN Palopo selesai dilakasanakan, maka tahap selanjutnya adalah melakukana evaluasi (evaluating). Hasil pengukuran parameter $Q o S$ yang terdiri dari Bandwidth, throughput, Delay, Jitter dan Packet loss dapat di evaluasi dan analisis dengan penjelasan sebagai berikut :

1) Qouta Bandwidth untuk Aplikasi

Metode implementasi $Q o S$ pada jaringan Internet IAIN Palopo untuk parameter Bandwidth adalah dengan pengendalian traffic jaringan dengan melakukan bandwidth management. Besar Bandwidth yang diperoleh dari ASTINET sebesar 8 Mps diatur sedemikian rupa dengan pemberian Quota Bandwidth sebagai berikut : Aplikasi sebesar $124 \mathrm{kbps}$ - $3 \mathrm{Mbps}$, yang meliputi beberapa aplikasi yang ada pada Kampus IAIN Palopo antara lain penanganan LAN pada Gedung Perpustakaan yang sistemnya menerapkan sistem online Library, demikian juga sistem LAN pada Gedung Rektorat. Untuk Dosen/Staff diberikan quota sebesar 124 kbps - 3 Mbps, untuk Mahasiswa diberikan quota sebesar 256 / 512 Kbps. Sedangkan sisa dari Bandwidth yang ada digunakan untuk Baypass, gunanya agar tidak terjadi overload dalam pemakaian Bandwidth itu sendiri. Dari hasil pengukuran bandwidth melalui monitoring, diperoleh hasil sebagai berikut :

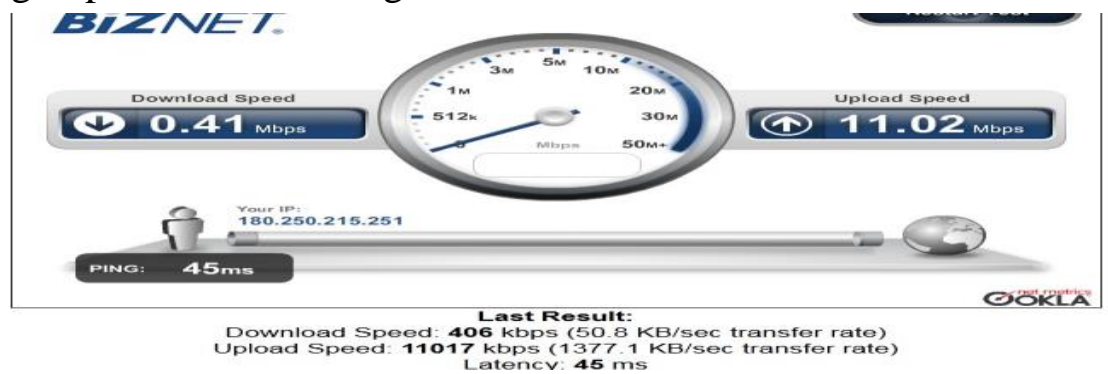

Gambar 2. Monitoring biznet untuk quota bandwidth aplikasi 


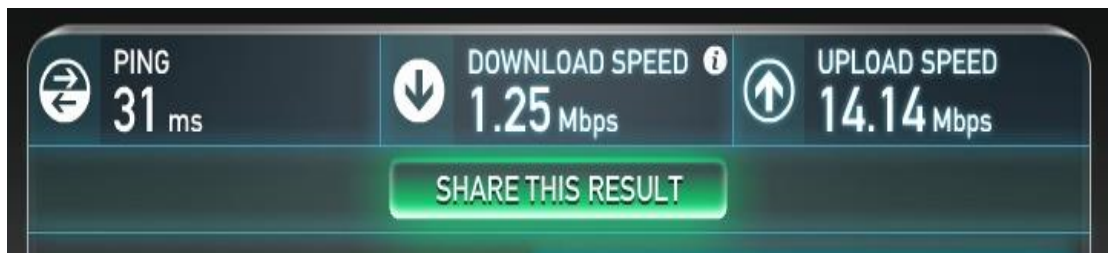

Gambar 3. Monitoring speedtest untuk quota bandwidth aplikasi

Penggunaan dua model monitoring yang ada dengan mempertimbangkan pengukuran di waktu yang sama nampak jelas perbedaan yang tidak terlalu mencolok antara pengukuran dengan Biznet maupun speed test, dengan diperoleh download speed rata-rata $0.83 \mathrm{Mbps}$ sedanghkan Upload speed rata-rata 12,58 Mbps.

Sementara nilai Latency atau delay yang diperoleh adalah $45 \mathrm{~ms}$ itu berarti delay yang ada pada jaringan internet IAIN Palopo bisa dikatakan sangat bagus untuk quota bandwidth yang diberikan ke Aplikasi.

2) Qouta Bandwidth untuk Dosen dan Staff

Pada pembagian quota Bandwidth untuk dosen dan staff diberikan $124 \mathrm{kbps}$ 3 Mbps, setelah melalui pengukuran dengan pantauan monitoring yang ada diperoleh sebagai berikut :

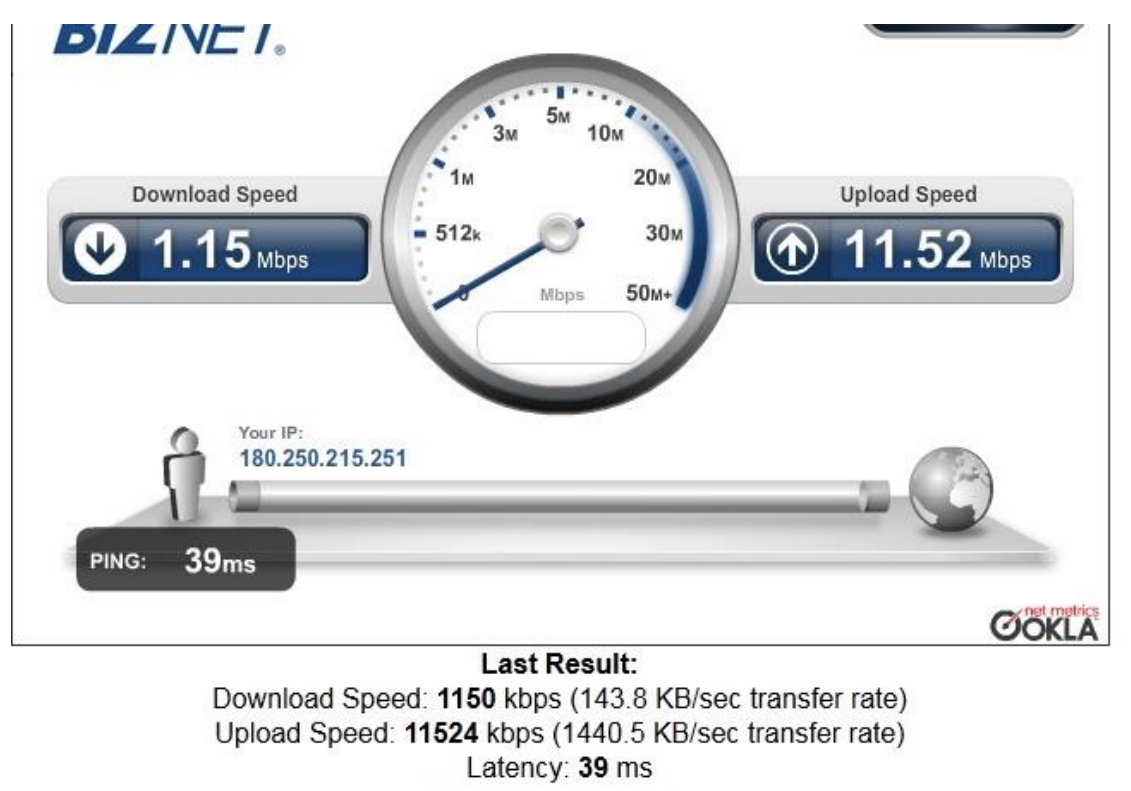

Gambar 4. Monitoring biznet untuk quota bandwidth dosen/staff

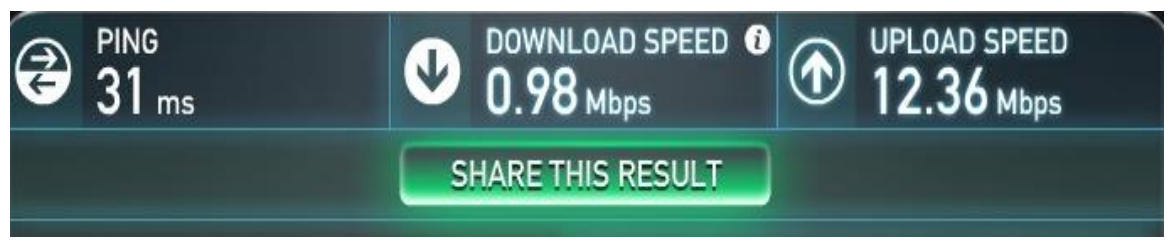

Gambar 5. Monitoring speedtest untuk quota bandwidth dosen/staff

Dari pantauan yang ada diperoleh nilai Bandwidt rata-rata untuk Download speed sebesar 1,02 Mbps, sedangkan untuk upload speed sebesar 11,22 Mbps dengan 
nilai Delay sebesar 39 ms maka dapat pula dikatakan delay yang terjadi pada qouta bandwidth dosen dan staff sangat bagus.

3) Qouta Bandwidth untuk Mahasiswa

Quota Bandwidth Mahasiswa sebesar 256 / 512 Kbps dengan jumlah user setiap harinya rata-rata lebih dari 70- 125 user, sehingga dapat dipantau dengan hasil sebagai berikut :

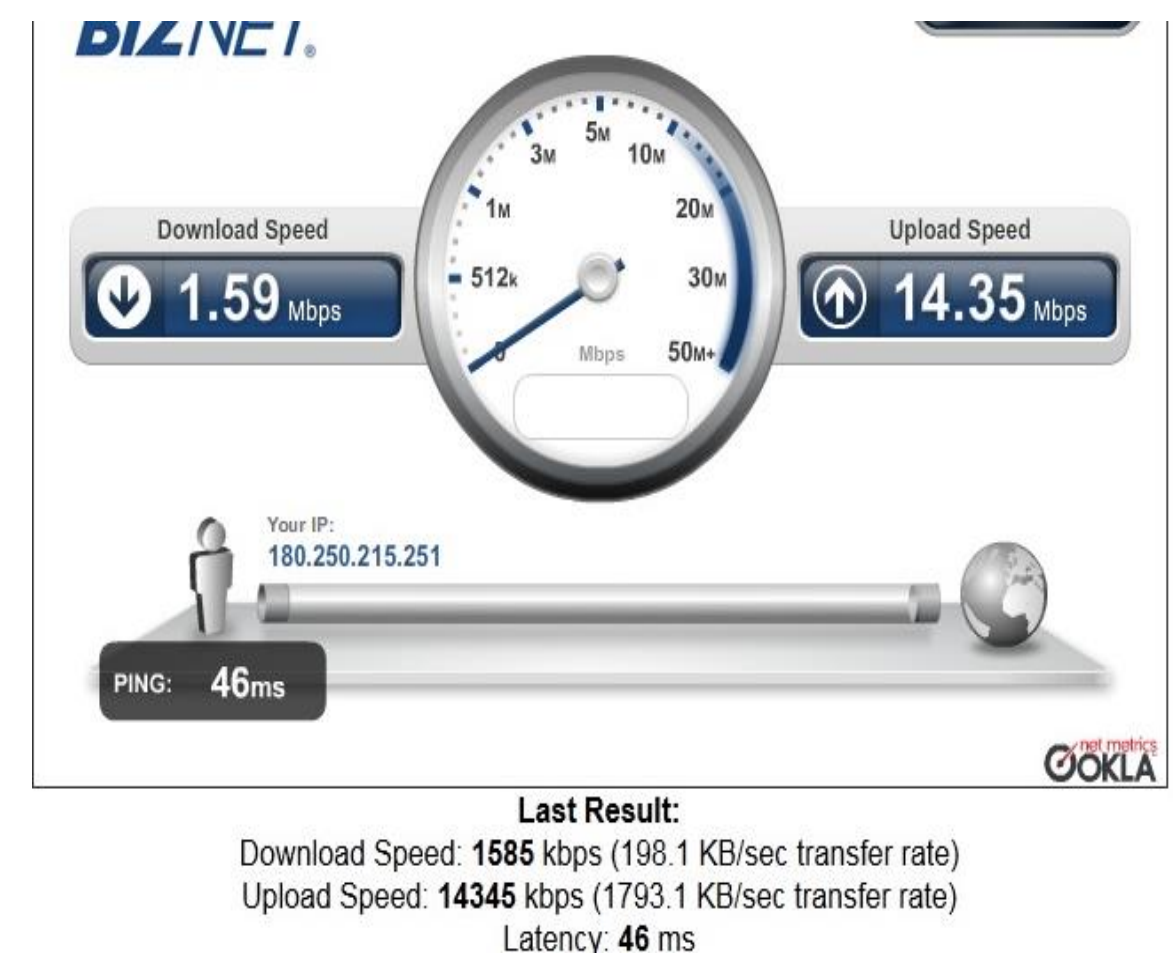

Gambar 6. Monitoring biznet untuk quota bandwidth mahasiswa

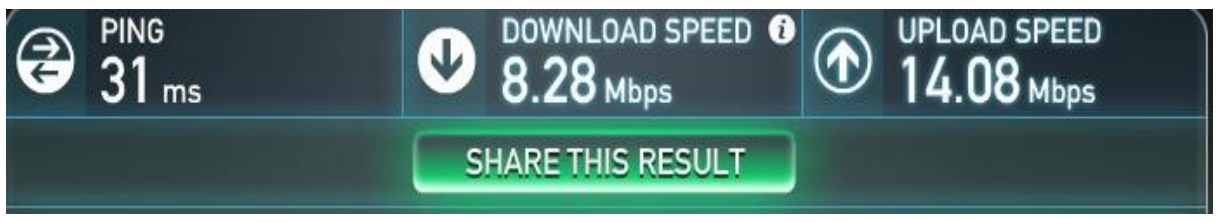

Gambar 7. Monitoring speedtest untuk quota bandwidth mahasiswa

Diperoleh nilai bandwidth yang melampaui dari nilai quota yang diberikan namun hal ini dapat teratasi karena masih ada sisa bandwidth yang digunakan pada quota Baypass. Adapun besar download speed denganpengukuran Biznet berkisar 1-2 Mbps sedangkan untuk upload speed nya 14,30 Mbps, sebagai pertimbangan terdapat perbedaan yang signifikan antara pengukuran dengan monitoring Biznet dan speed test dikarenakan biasa terjadi overload bandwidth pada quota bandwidth mahasiswa. Meskipun demikian nilai delay yang dihasilkan dapat dikatakan sangat bagus karena $<150 \mathrm{~ms}$ yaitu $46 \mathrm{~ms}$. 
4) Pantauan Terhadap Bandwidth Perlakuan Non Quota

Setelah mendapatkan hasil terhadap besarnya nilai bandwidth yang ada pada setiap qouta yang diberikan untuk aplikasi, Dosen dan staff serta mahasiswa maka diberikan perlakuan tanpa quota, maka diperoleh hasilnya sebagai berikut :

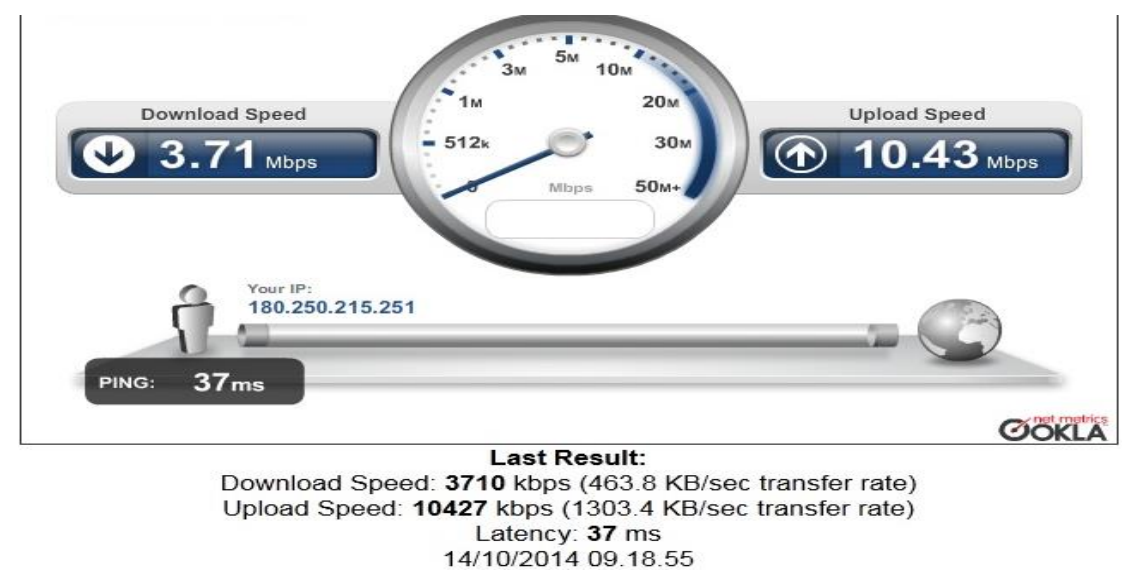

Gambar 8. Monitoring biznet untuk non quota bandwidth

Dari monitoring Biznet di atas terlihat bahwa terjadi overload dalam pemakaian Bandwidth untuk Upload speed yang mana jatah Bandwidth dari ASTINET hanya 8 Mbps tapi untuk non qouta ini terlihat sampai mencapai angka 10,43 Mbps. Hal ini sangat berpengaruh terhadap koneksitas jaringan yang tersedia sehingga dapat mengakibatkan lambatnya jaringan internet yang digunakan oleh user dalam waktu yang bersamaan, sehingga solusi pembagian bandwidth berdasarkan kebutuhan untuk masing-masing unsur dalam lingkup IAIN Palopo sangat membantu.

\section{5) Throughput}

Throughput merupakan jumlah total kedatangan paket yang sukses yang diamati pada destination selama interval waktu tertentu dibagi oleh durasi interval waktu tersebut. Throughput adalah kemampuan sebenarnya suatu jaringan dalam melakukan pengiriman data. Biasanya throughput selalu dikaitkan dengan bandwidth. Karena throughput memang bisa disebut juga dengan bandwidth dalam kondisi yang sebenarnya. Bandwidth lebih bersifat fix sementara throughput sifatnya adalah dinamis tergantung trafik yang sedang terjadi.

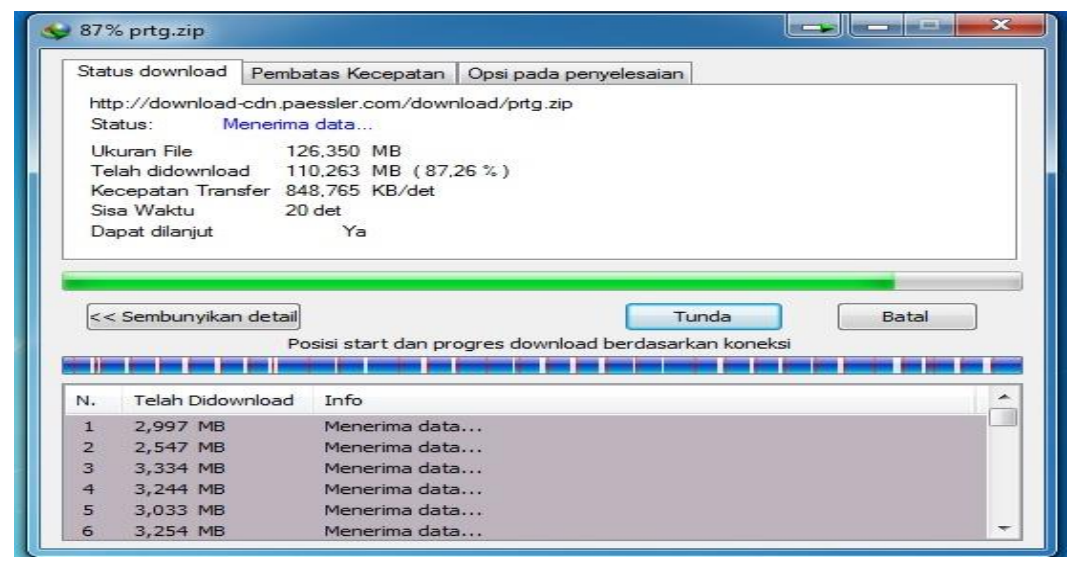

Gambar 9. Througput jaringan IAIN Palopo 
6) Delay

Delay dapat dipengaruhi oleh jarak, media fisik atau juga waktu proses yang lama dalam jaringan $L A N$. Menurut versi TIPHON, sebagai standarisasi yang digunakan dalam pengukuran nilai delay, maka besarnya delay dapat diklasifikasikan sebagai kategori latensi sangat bagus jika $<150 \mathrm{~ms}$, bagus jika $150 \mathrm{~ms}$ s.d $300 \mathrm{~ms}$, sedang jika $300 \mathrm{~ms}$ s.d $450 \mathrm{~ms}$ dan jelek jika > $450 \mathrm{~ms}$. Berdasarkan hasil pengukuran nilai delay terhadap skema perangkat jaringan di IAIN Palopo didapat nilai rata-rata response time delay sebesar $44 \mathrm{~ms}$, sehingga dapat dikatakan sangat bagus.

7) Packet Loss

Berdasarkan hasil pengukuran terhadap skema perangkat jaringan $L A N$ di IAIN Palopo didapat nilai packet loss dalam persentase (\%) untuk setiap perangkat. Faktor penyebab packet Loss dapat terjadi karena collision atau taabrakan/tumbukan antara data pada jaringan dan hal ini berpengaruh pada semua aplikasi yang ada di jaringan LAN IAIN Palopo karena retransmisi akan mengurangi efisiensi jaringan secara keseluruhan meskipun jumlah bandwidth cukup tersedia untuk aplikasiaplikasi tersebut. Umumnya perangkat jaringan memiliki buffer untuk menampung data yang diterima. Jika terjadi kongesti atau kelebihan beban dalam jaringan LAN yang cukup lama, buffer akan penuh, dan data baru tidak akan diterima, hal inilah yang bisa menyebabkan packet Loss.

\section{PENUTUP}

Dari analisis hasil pengukuran terhadap lima parameter $Q o S$ terdapat faktorfaktor yang mempengaruhinya ada perbedaan hasil pengukuran antara setiap VLAN. Perbedaan ini dipengaruhi oleh adanya redaman terhadap sinyal yang ditransmisikan pada medium kabel twisted pair dan udara yang menghubungkan. Distorsi yang merupakan kecepatan sinyal yang melalui medium yang berbeda antara setiap VLAN juga berpengaruh terhadap perbedaan hasil pengukuran antara setiap VLAN. Selain itu noise yang merupakan gangguan terhadap sinyal yangdikirimkan antara pengirim dan penerima juga berpengaruh, disamping pembagian bandwidth untuk setiap $V L A N$. Parameter kualitas layanan atau QoS yang terdiri dari bandwith, troughtput, delay, jitter dan packet loss terhadap QoS jaringan Internet pada STAIN Palopo, terutama pada Trafic Bisnis Critical atau Internet untuk tiap-tiap perangkat atau enduser sangat berpengaruh. Faktor-faktor yang bisa mempengaruhi $Q o S$ jaringan Internet pada STAIN Palopo adalah redaman, distorsi dan noise. Kapasitas Bandwidthh yang tersedia juga berpengaruh terhadap $Q o S$.

Peranan dari pembagian quota bandwidth sangat mempengaruhi $Q o S$ dari trafik. Oleh Karena itu untuk mendapatkan $Q o S$ yang baik, diperlukan pengaturan pemakaian bandwidthh dalam jaringan sebaik mungkin. Cara yang bisa di pakai dengan teknik klasifikasi paket data $C B Q$ (Class Based Queue) yang sudah diterapkan atau HTB (Hierarchy Token Bucket) yang merupakan teknik terbaru. Selain itu dalam usaha menjaga dan meningkatkan nilai $Q o S$, dibutuhkan teknik untuk menyediakan utilitas jaringan, yaitu dengan mengklasifikasikan dan memprioritaskan setiap informasi sesuai dengan karakteristiknya. 


\section{DAFTAR PUSTAKA}

Anonim, 2003, Bandwidth Management and Queuing, Cisco System Inc., http://www.cisco.com.

Anonim, 2003, Policing and Shaping Overview, Cisco System Inc. http://www.cisco.com.

BIZNET, BIZNET METRO Bandwidth Meter, (http://www.-biznetnetworks.com/Id/).

Blommers John,, Practical Planning for Network Growth, Prentice Hall, New Jersey 1996.

Chandrax 2008, Action Research/Penelitian Tindakan, 31 Juli 2008, (http://chandrax.net76-.net/?p=7).

Croll Alistair, Managing Bandwidth Deploying QoS in Enterprise Networks, Prentice Hall, New Jersey, 2000.

Fatoni, Analisis Kualitas Layanan Intranet, Universitas Bina Darma Palembang, 2003.

Fikri, Zainal, Filsafat Umum : Analisis Konsep, 2 September 2007, (http://zfikri.wordpress.com/2007/ 09/02/-filsafat umum-analisiskonsep/).

Gunawan, Arif Hamdani, Quality of Service dalam Data Komunikasi,, 8 Mei2008, (http://telecommunicationforall.blogspot.com/2008/05/ qualityservice.html).

Jogiyanto, Pengenalan Komputer , ; Andi- Jogyakarta, 2005.

Joesman, Simulasi Jaringan berbasis paket dengan memper-gunakan simulator OPNET, 3 April 2008, (http://joesman.wordpress.com/ page/2/).

Kamarullah, A. Hafiz, 'Penerapan Metode Quality of Service pada Jaringan Trafic yang Padat', Jurnal Jaringan Komputer Universitas Sriwijaya, (www.unsri.ac.id/.../A\%20Hafiz\%20Kamarullah (09061002056). doc).

Michael E. Flanaga, Administering Cisco QoS in IP Network, SYNGRESS, 2002.

MustNoFee, Testing Network Limit with Iperf, (http://www.mustnofee.com/ component/content/article/68-testing-network-limitwith-iperf).

Ningsih, Yuli Kurnia dkk , 'Analisis QualitYOf Service (Qos) pada Simulasi Jaringan Multiprotocol Label Switching Virtual Private Network (Mpls Vpn)',JETri,vol.3,no.

2 , (http://blog.trisakti.ac.id/jetri/2010/01/17/analisis-quality-of-service-qospadasimulasi-jaringan-multiprotocol labelswitching - virtual-privatenetwork-plsvpn/).

Putri, Marseli Eka, 'Penerapan Metode QOS untuk Traffic yang Padat', Teknik Informatika Bilingual Fakultas Ilmu Komputer Universitas Sriwijaya 2009-2010,(http://www.unsri.ac.id/upload /arsip/Marseli Eka Putri (59061002033)doc).

Rahadi, Dedi Rianto, Proses Riset Penelitian, Tunggal Mandiri Publishing, Malang.2003.

Sofa, Pakde, Logika, Penalaran dan Analisis Definisi, (http://massofa.wordpress.com/2008/01/31/-logikapenalaran-dananalisis-definisi/>. 